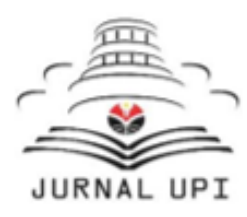

THE JOURNAL GASTRONOMY TOURISM

Volume 3 Nemor 1 , Juni 2016, 40-48

Available online at:

https://ejournal.upi.edu/index.php/gastur

\title{
EVALUASI KELAYAKAN BISNIS DI RESTORAN SANGKURIANG BANDUNG DARI ASPEK OPERASIONAL
}

\author{
Dhini Unggul Pramesti, Agus Sudono, Oce Ridwanudin \\ Program Studi Manajemen Industri Katering \\ Fakultas Pendidikan Ilmu Pengetahuan Sosial \\ Universitas Pendidikan Indonesia
}

\begin{abstract}
Evaluate the feasibility has been widely known by the public, especially people who are engaged in the business world. This experiment aims to determine the feasibility evaluation overview Sunda and Oriental Restaurants in Bandung, which in terms of feasibility operasional.Evaluasi aspects needed to see a picture of decent atu not like a business to run.

The method used is descriptive qualitative research methods. Methods of data collection is done by conducting interviews and observations. Sampling technique used is nonprobability. Data analysis technique used is the SWOT matrix with IE matrix analysis, IFAS and EFAS. Based on the research results, obtained that picture business viability in Bandung Restaurant Sangkuriang declared eligible.

Results of internal and external factors in the operation were at high levels. The operational aspects of the matter Weight gain by 3.13 SWOT Matrix internal factors and external factors, which means 3,07 Sangkuriang Bandung Restaurant is eligible to run.
\end{abstract}

Keywords: Feasibility Study in Business, Management Strategy.

\section{ABSTRAK}

Evaluasi kelayakan telah banyak di kenal oleh masyarakat, terutama masyarakat yang bergerak dalam bidang dunia usaha. Penelitin ini bertujuan untuk mengetahui evaluasi gambaran kelayakan bisnis Restoran Sunda dan Oriental di Kota Bandung yang dari segi aspek operasional.Evaluasi kelayakan usaha diperlukan untuk melihat sebuah gambaran mengenai layak atu tidak layaknya suatu usaha yang akan dijalankan. Metode yang digunakan adalah metode penelitian deskriptif kualitatif.

Metode pengumpulan data dilakukan dengan melakukan wawancara dan observasi. Teknik sampel yang digunakan adalah nonprobability. Teknik analisis data yang digunakan adalah Matriks SWOT dengan analisis matriks IE, IFAS dan EFAS.

Berdasarkan hasil penelitian, diperoleh bahwa gambaran kelayakan bisnis di Restoran Sangkuriang Bandung dinyatakan layak. Hasil dari faktor internal dan eksternal dalam operasional berada di tingkat yang tinggi. Aspek operasional ini memperoleh dari hitungan Bobot Matriks SWOT sebesar 3,13 faktor internal dan 3,07 faktor eksternal yang artinya Restoran Sangkuriang Bandung ini layak dijalankan.

Kata kunci: Studi Kelayakan Bisnis, Management Strategy. 


\section{PENDAHULUAN}

Restoran Sangkuriang adalah Restoran Sunda modern dengan menu unggulan yang memanfaatkan produk asli daerah Subang khususnya Ikan air tawar. Maka beraneka menu tercipta dari bahan baku ikan air tawar, seperti Sup Ikan, Ikan bakar asap, Ikan Goreng Kering, Ikan Acar Kuning, Pesmol Ikan, Pindang ikan, Pepes Ikan, Ikan Asam Manis, Ikan renyah pedas, yang dikombinasikan dengan menu-menu lainnya yang berupa masakan dari daging, ayam, sayuran, minuman, dan lain-lain. Dari sekian banyak menu Restoran Sangkuriang, yang menjadi ikon Sangkuriang itu sendiri adalah "Sup Ikan" yang memiliki rasa dan tampilan yang khas, dengan menyajikan aroma khas daun kemangi segar.

Selain unggul dalam produk dengan bahan baku alami dan fresh, Restoran Sangkuriang juga memiliki lokasi yang strategis, terletak di daerah pegunungan yang sejuk, dengan background alam pesawahan dan hutan yang masih asli, ditambah dengan konsep bangunan tradisional dengan dilengkapi fasilitas Lesehan di atas kolam ikan, menjadikan minat masyarakat kota khususnya yang berasal dari Jakarta dengan tujuan Ciater dan Tangkuban Perahu untuk mampir ke Restoran Sangkuriang sambil beristirahat sejenak setelah melakukan perjalanan jauh, menikmati masakan khas Sangkuriang dan menikmati pemandangan alamnya.

Dalam perkembangannya Restoran Sangkuriang sukses menarik konsumen, sehingga mampu bertahan dan berkembang dengan pesat. Sehingga dalam waktu yang tidak terlalu lama Nama Restoran Sangkuriang sudah dikenal di kalangan penikmat kuliner di kota besar yang melakukan perjalanan ke Daerah Subang. Pada tahun 2005 akses ke kota Bandung, Ciater dan Tangkuban Parahu di permudah dengan dibukanya Jalan Tol Cipularang, sehingga perjalanan dari Jakarta ke Bandung cukup ditempuh dalam waktu rata-rata hanya 2 jam saja. Perkembangan ini di satu sisi memudahkan para wisatawan baik lokal maupun mancanegara untuk berkunjung ke Bandung dan sekitarnya, Namun di sisi lain cukup berpengaruh kepada pengusaha rumah makan yang beroperasi di jalur Cikampek, Kopo, Sadang Purwakarta, Kalijati dan Subang, karena dengan dibukanya akses baru tersebut secara otomatis mengurangi lalulintas wisatawan ke daerah-daerah tersebut. Maka tidak heran banyak rumah makan di daerah tersebut yang menurun drastis omsetnya, bahkan ada diantaranya yang tutup karena sudah tidak mampu untuk membiayai kegiatan operasionalnya.

Menyikapi hal tersebut pemilik Restoran Sangkuriang berencana untuk melebarkan sayap dan membuka Cabang di Kota Bandung. Maka Sekitar bulan Desember tahun 2005 berdirilah Restoran Sangkuriang di Jalan Karang Sari No 5 Setiabudhi Bandung.

Tabel 1.1

Jumlah pendapatan Restoran Sangkuriang

\begin{tabular}{|c|c|c|c|l|c|c|}
\hline \multirow{2}{*}{ No } & \multicolumn{2}{|c|}{ Tahun 2013 } & \multicolumn{2}{c|}{ Tahun 2014 } & \multicolumn{2}{c|}{ Target 2014 } \\
\cline { 2 - 7 } & \multicolumn{2}{|c|}{ Bulan } & \multicolumn{2}{|c|}{ Bulan } & \multicolumn{2}{c|}{ Bulan } \\
\hline 1 & Januari & $\operatorname{Rp~57.758.789}$ & Januari & Rp 260.493.893 & Januari & 350.000 .000 \\
\hline 2 & Febuari & $\operatorname{Rp~61.163.064}$ & Febuari & Rp 120.110.800 & Febuari & 350.000 .000 \\
\hline 3 & Maret & Rp. 59.221.456 & Maret & Rp 157.857805 & Maret & 350.000 .000 \\
\hline 4 & April & $\operatorname{Rp~33.914.048}$ & April & $\operatorname{Rp~135.625.315~}$ & April & 350.000 .000 \\
\hline 5 & Mei & $\operatorname{Rp~42.015.349}$ & Mei & Rp 143.217.960 & Mei & 350.000 .000 \\
\hline
\end{tabular}




\begin{tabular}{|c|c|c|c|l|c|c|}
\hline 6 & Juni & $\operatorname{Rp~13.101.395~}$ & Juni & $\operatorname{Rp~135.870.795~}$ & Juni & 350.000 .000 \\
\hline 7 & Juli & $\operatorname{Rp~35.675.765~}$ & Juli & $\operatorname{Rp~203.349.590~}$ & Juli & 350.000 .000 \\
\hline 8 & Agustus & $\operatorname{Rp~51.816.244~}$ & Agustus & $\operatorname{Rp~352.879.485~}$ & Agustus & 350.000 .000 \\
\hline 9 & September & $\operatorname{Rp~90.027.369~}$ & September & $\operatorname{Rp~136.025.505~}$ & September & 350.000 .000 \\
\hline 10 & Oktober & $\operatorname{Rp~64.414.125~}$ & Oktober & $\operatorname{Rp~151.497.520~}$ & Oktober & 350.000 .000 \\
\hline 11 & November & $\operatorname{Rp~133.623.692~}$ & November & $\operatorname{Rp~151.318.580~}$ & November & 350.000 .000 \\
\hline 12 & Desember & $\operatorname{Rp~116.078.615~}$ & Desember & $\operatorname{Rp~302.819.210~}$ & Desember & 350.000 .000 \\
\hline \multicolumn{2}{|l|}{ Total } & $\operatorname{Rp~758.809.911}$ & Total & $\operatorname{Rp} 2.251 .066 .458$ & & \\
\hline \multicolumn{2}{|l|}{ Perbulan } & $\operatorname{Rp~63.234.159.25~}$ & Perbulan & $\operatorname{Rp~187.588.871}$ & & \\
\hline
\end{tabular}

Sumber: Manajemen Sangkuriang, 2015

Tabel 1.1 menjelaskan bahwa pendapatan pada tahun 2013 dan 2014 terdapat perbedaan yang cukup signifikan pada tahun 2013 pendapatan berjumlah Rp.758.809.911 sedangkan pada tahun 2014 berjumlah Rp.2.251.066.458 walaupun mengalami kenaikan tetapi target restoran sangkuriang sebesar Rp.350.000.000 perbulan belum $100 \%$ tercapai, terlihat pada bulan febuari, maret, april, mei, juni, september, oktober dan november penjualan di bawah target sedangkan pada bulan agustus tahun 2014 penjualan melampui target namun hal ini terjadi lebaran dan liburan sekolah. Maka terlihat ada permasalahan yang timbul di Restoran Sangkuriang.

Tabel 1.2

Jumlah biaya operasional Restoran Sangkuriang

\begin{tabular}{|l|l|}
\hline Food cost 2013 & Rp 197.321.349 \\
\hline Food cost 2014 & Rp 200.334.262 \\
\hline
\end{tabular}

Sumber: Manajemen Sangkuriang 2015

Masalah terlihat dari perbandingan biaya operasional dengan pendapatan pertahun dimana jumlah biaya operasional lebih besar dari pada jumlah pendapatan. Mengakibatkan banyakanya kendala dalam masalah operasional seperti bayar sewa tempat, pajak, pembayaran gaji dan menghambat pada biaya produksi. oleh karena itu restoran Sangkuriang melakukan strategi penyusunan aspek operasional seperti proses penyusunan fasilitas yang dipakai untuk memproduksi barang dan jasa karena di restoran Sangkuriang tidak adanya penerapan yang maksimal hal berdampak pada peralatan memasak sering terjadi kerusakan, persediaan pemesanan bahan baku di Restoran Sangkuriang juga mengalami masalah karena banyak bahan baku yang terbuang, kualitas dalam penerapan SOP dan SDM yang ada di dalam Restoran tersebut masih mengalami kekurangan dalam penerapanya.

Upaya yang dilakukan Restoran Sangkuriang untuk memperbaiki dan meningkatkan aspek operasional adalah dengan memperbaiki sistem kerja karyawan dan manager untuk saling menghargai agar mendapatkan suasana kerja yang nyaman, sehingga meningkatkan kualitas kerja yang baik antara manager dan karyawan dan melakukan briefing setiap harinya agar penerapan SOP bisa di terapkan dengan baik oleh para karyawan.

Berdasarkan uraian di atas, mengenai kendala dalam operasional restoran sangkuriang penulis tertarik untuk meneliti dengan judul "EVALUASI KELAYAKAN BISNIS DI RESTORAN SANGKURIANG BANDUNG DARI ASPEK OPERASIONAL". 
Berdasarkan Latar Belakang di atas maka penulis merumuskan masalah sebagai berikut:

1. Mengidentifikasi hal apa saja yang sudah terjadi di restoran Sangkuriang Bandung dari segi aspek operasional?

2. Mengevaluasi kelayakan usaha restoran Sangkuriang Bandung dari segi aspek operasional ?

3. Langkah apa saja yang diupayakan untuk membuat perusahaan tersebut layak atau tidak layak untuk dilanjutkan dari segi aspek operasional ?

\section{PEMBAHASAN}

SWOT adalah semua organisai memiliki kekuatan dan kelemahan dalam area fungsional bisnis. Kekuatan dan kelemahan internal di gabungkan dengan peluang atau ancaman dari eksternal dan pernyataan misi yang jelas, menjadi dasar penetapan tujuan dan strategi.

1. Kekuatan (Streghts)

Kekuatan adalah sumber daya, keterampilan, atau keunggulan-keunggulan lain yang berhubungan dengan para pesaing perusahaan dan kebutuhan pasar yang dapat dilayani oleh perusahaan yang diharapakan dapat dilayani.

2. Kelemahan (Weeknes)

Kelemahan adalah keterbatasan atau kekurangan dalam sumber daya, keterampilan, dan kapabilitas yang secara efektif menghambat kinerja perusahaan

3. Peluang (Opportunities)

Peluang adalah situasi penting yang mennguntungkan dalam lingkungan perusahaan kecendrungan-kecendrungan pentig merupakan salah satu sumber peluang, seperti perubahan teknologi dan meningkatnya hubungan antara perusahaan dengan pembeli atau pemasok merupakan gambaran peluang bagi perusahaan.

4. Ancaman(Threats)

Ancaman adalah situasi penting yang tidak menguntungkan dalam lingkungan perusahaan. Ancaman pengganggu utama bagi posisi sekarang atau yang diingikan perusahaan danya peraturan-peraturan pemerintah yang baru atau yang direvisi dapat anacaman bagi kesuksesan perusahaan.

\section{Faktor Lingkungan Internal}

Berdasarkan hasil wawancara dengan owner Restoran Sangkuriang Bandung

yang memeberikan pendapat dan penilaian faktor-faktor opersional Restoran Sangkuriang di Bandung diperoleh sebagai berikut:

Faktor Kekuatan Internal:

1. Ciri Khas Menu

Menu yang Restoran tawarkan adalah Ikan sebagai menu utama yang tidak dimiliki oleh restoran lain.

2. Proses Prduksi 
Alur penerimaan bahan baku hingga tahap pengolahan bahan baku sudah terlaksana dengan baik,sehingga tidak mempengaruhi kepada alur produksi sampai ke para konsumen.

3. Sumber Daya Manusia

Kualitas dalam SDM restoran sangkuriang sudah baik dan tidak bermasalah hanya perlu diberikan pelatihan setiap bulanya

Faktor Kelemahan Internal:

1. Peralatan

Peralatan di restoran sangkuring kurang memadai terlihat dari peralatan yang sudah di pkai dan belum di perbarrui, lalu perlengkapan masih kurang jumlah seperti piring, sendok, garpuh, cup, dask spoon dll.

2. Catatan Pembukuan

Restoran sangkuriang belum memiliki catatan pembukuan yang mendetail sehingga sering terjadi nya miss komunikasi antara karyawan satu dengan lainya.

3. Loading dock

luasnya tempat parkir berepengaruh terhadap datagnya mobil besar untuk penyimpanan bahan baku yang tidak harus memasuki restoran karena sudah ada tempat khusus yang bisa memasukan bahan baku ke gudang.

4. Waktu tunggu pemesanan

Setiap restoran ingin memberikan yang terbaik untuk para konsumen, tetapi jika konsumen menunggu makanan lama datang menimbulkan kebosanan.

5. Haraga Bahan baku

Harga bahan baku dari supplier sangat berpengaruh terhadap penjualan dan berpengaruh terhadap keputusan pembelian konsumen.

6. Supplier

Kualitas bahan baku, harga dan kuantitas bereperan penting dalam menjalin kerja sama dengan supplier, akan tetapi restoran sudah memiliki spesifikasi tertentu terhadap pengambilan bahan baku.

Faktor Ancaman Eksternal:

1. Persaingan restoran

Usaha yang lain dengan bisnis yang sama.

2. Kenaikan harga bbm

Yang akan mempengaruhi terhadap kelangkaan bahan baku

3. Kelangkaan bahan baku

Dapat mempengaruhi jumlah produksi dan terhadap harga jual

Faktor Peluang Eksternal

1. Daya beli masyrakat

Meningkatnya keinginan masyarakat untuk berwisata kuliner berpengaruh terhadap restoran.

2. Perkembangan Teknologi

Semakin berkembangnya teknologi canggih dan banyaknya media sosial saat ini membuka peluang promosi gratis pada restoran sangkuriang.

3. Perkembangan Pariwisata kuliner 
Semakin pesat dan luas perdagangan, industri pariwisata dan industri kuliner peluang bagi para perusahaan untuk meningkatkan penjualan.

\section{Analisis Matriks IFAS dan EFAS}

Analisis Matriks IFAS (Internal Factors Analisis Summary)

Matriks IFE (Internal Faktor Evaluation) digunakan untuk mengevaluasi faktor-faktor internal perusahaan berkaitan dengan kekuatan dan kelemahan. Berdasarakan analisis terhadap identifikasi faktor internal Restoran Sangkuriang Bandung maka didapatkan 4 kekuatan dan 4 kelemahan yang kemudian akan diberikan penilaian dengan memberikan bobot.

Tabel 4.1

Matriks IFAS (Internal Factors Analisis Summary) Restoran Sangkuriang Bandung

\begin{tabular}{|c|c|c|c|c|}
\hline \multirow{2}{*}{ No } & \multirow{2}{*}{ Faktor Internal } & \multirow{2}{*}{ Bobot } & \multirow{2}{*}{ Rating } & \multirow{2}{*}{$\begin{array}{c}\text { NilaiTertimbang } \\
\mathbf{c}=\mathbf{a} \mathbf{x} \mathbf{b}\end{array}$} \\
\hline & & & & \\
\hline \multicolumn{5}{|c|}{ Kekuatan (Strengths) } \\
\hline 1 & Ciri khas menu & 0.13 & 4 & 0,52 \\
\hline 2 & Proses produksi & 0,12 & 3 & 0,36 \\
\hline 3 & Sumber daya manusia & 0.12 & 3 & 0,36 \\
\hline \multicolumn{5}{|c|}{ Kelemahan (Weakness) } \\
\hline 4 & Peralatan & 0.12 & 3 & 0,36 \\
\hline 5 & Catatan pembukuan & 0.12 & 2 & 0,36 \\
\hline 6 & Loading dock & 0.11 & 3 & 0,33 \\
\hline 7 & Supplier & 0,09 & 3 & 0,27 \\
\hline 8 & Harga bahan baku & 0,10 & 3 & 0,3 \\
\hline 9 & Waktu tunggu pemesanan & 0.09 & 2 & 0,27 \\
\hline & Total & 1.00 & & 3,13 \\
\hline
\end{tabular}


Berdasarkan hasil pada data tabel 4.1 Maka total skor faktor internal adalah 3,13 angka ini menunjukan kategori kuat karena berada diatas 2,50. Ini menunjukan bahwa posisi internal strategi pengembangan restoran Sangkuriang Bandung dikatakan kuat sehingga mampu memanfaatkan faktor-faktor kekuatan yang ada untuk dapat mengatasi faktor-faktor kelemahanya.

\subsubsection{Analisis Matriks EFAS (Eksternal Factors Analisis Summary)}

Matriks EFE (Eksternal Faktor Evaluation) digunakan untuk mengevaluasi faktor-faktor internal perusahaan berkaitan dengan peluang dan ancaman. Berdasarakan analisis terhadap identifikasi faktor eksternal Restoran Sangkuriang Bandung maka didapatkan 3 peluang dan 3 ancaman yang kemudian akan diberikan penilaian dengan memberikan bobot.

\section{Tabel 4.2}

Matriks EFAS (Eksternal Factors Analisis Summary) Restoran Sangkurian Bandung

\begin{tabular}{|c|l|c|c|c|}
\hline \multirow{2}{*}{ No } & \multicolumn{1}{|c|}{ FaktorEsternal } & \multirow{2}{*}{ Bobot } & Rating & NilaiTertimbang \\
\cline { 3 - 5 } & & & & $\mathbf{c}=\mathbf{a ~ x ~ b ~}$ \\
\hline $\mathbf{1}$ & Daya beli masyrakat & 0.18 & 4 & 0,72 \\
\hline $\mathbf{2}$ & Perkembangan Teknologi & 0.18 & 3 & 0,54 \\
\hline $\mathbf{3}$ & $\begin{array}{l}\text { Pekembangan pariwisata } \\
\text { kuliner }\end{array}$ & 0.18 & 3 & 0,54 \\
\hline \multicolumn{5}{|c|}{ Ancaman(Threat) } \\
\hline $\mathbf{1}$ & Persaingan restoran & 0,18 & 3 & 0,54 \\
\hline $\mathbf{2}$ & Kenaikan bahan bakar & 0.17 & 3 & 0.51 \\
\hline $\mathbf{3}$ & Kelangkaan bahan baku & 0.11 & 2 & 0.22 \\
\hline Total & & $\mathbf{1 . 0 0}$ & & $\mathbf{3 , 0 7}$ \\
\hline
\end{tabular}

\section{Analisis Matriks IE (Internal-Eksternal)}

Matriks IE didasarkan pada dua dimensi kecil yaitu skor bobot IFAS pada sumbu x dan skor bobot EFAS total pada sumbu y. Skor bobot total yang diperoleh dari divisi-divisi tersebut memungkinkan susunan matriks IE di tingkat perusahaan. 
Berdasarakan dari analisis matriks IFAS terhadap faktor lingkungan internal menghasilkan total skor sebesar 3,13 yaitu diatas rata-rata nilai 2,50 yang berarti posisi faktor internalnya kuat sehingga perusahaan dapat memanfaatkan faktor kekuatan untuk mengatasi faktor kelemahan dari perusahaan.

Sedangkan berdasarkan dari analisis matriks EFAS terhadap faktor lingkungan eksternal mengghasilkan total skor sebesar 3,07 yaitu diatas nilai yang dimana posisi faktor eksternalnya tidak terlalu kuat sehingga perusahaan dapat memanfaatkan faktor peluang untuk mengatasi ancaman untuk perusahaan.

\section{Matriks Internal-Eksternal (IE) Restoran Sangkuriang Bandung}

Berdasarkan hasil analisis matriks internal dan eksternal dapat dilihat bahwa IFAS 3,13 sedangkan hasil EFAS 3,07 maka posisi restoran Sangkuriang berada pada tingkatan growth diversifikasi konsentrik yang merupakan kondisi competitive position sangat kuat, tetapi nilai daya tarik industrinya sangat rendah. Perushaan tersebut berusaha memnfaatkan kekuatanya untuk membuat produk baru secara efisien, karena perusahan ini sudah memiliki kemampuan manufaktur dan pemasaran yang baik.

Perusahaan yang berada pada tingkatan ini merupakan perusahaan yang mengacu pada kegiatan untuk meningkatkan lagi kualitas kinerja. Adapun diversifikasi yang terkait ketika rantai nilai bisnis memiliki kesesuaian strategis dan enam pedoman diversifikasi terkait dapat menjadi sebuah strategi yang efektif seperti:

- Ketika organisasi berkompetisi di sebuah industri yang tidak mengalami pertumbuhan atau yang pertumbuhannya lambat

- Ketika menambah produk yang baru namun terkait akan secara signifikan mendongkrak penjualan produk saat ini

- Ketika produk yang baru namun terkait dapat ditawarkan dengan harga yang sangat bersaing

- Ketika produk yang baru namun terkait memiliki tingkat penjualan musiman yang dapat mengimbangi puncak dan jurang penjualan yang ada saat ini di perusahaan

- Ketika produk organisasi yang ada saat ini sedang dalam tahap penurunan dari siklus hidup produk

- Ketika organisasi memiliki tim manajemen yang kuat

(Fred R. David, 2011:263)

\section{KESIMPULAN DAN SARAN}

\section{Kesimpulan}

Berdasarkan hasil penelitian yang sudah dilakukan, maka kesimpulan yang dapat diambil dari hasil evaluasi kelayakan bisnis di Restoran Sangkuriang Bandung aspek operasional adalah layak. di karenakan berdasarkan hasil dari Matriks SWOT penulis mendapatkan posisi Restoran Sangkuriang menunjukan growth diversifikasi konsentrik yang merupakan kondisi competitive position sangat kuat, tetapi nilai daya tarik industrinya sangat rendah. Perusahaan tersebut sudah berusaha memanfaatkan kekuatanya untuk membuat produk baru secara efisien dengan 
kemampuan manufaktur dan pemasaran yang baik. Namun masih terdapat beberapa hal yang perlu di perbaiki dalam aspek operasional meliputi produk, SDM, fasilitas, teknologi dan layout. Ada pun langkah-langkah yang dapat diupayakan untuk memperbaiki bisa dilihat dari Sub-Bab saran di bawah ini.

\section{DAFTAR PUSTAKA}

Atmojo, Marsum Widjojo. (2007). Restoran dan segala Permasalahanya.Yogyakarta: Andi

A, Y . O. (1991). Pengantar Ilmu Pariwisata. Bandung: Angkasa.

David, Fred R. (2008). Manajemen Strategis Konsep, Kasus dan Implementasi terjemahan. Jakarta. PT Gasindo.

Ebert J. Ronald. (2006). Bisnis atau Usaha. Erlangga Jakarta

Hunger, J.D dan Whelen. (2003). Management Strategis. Edisi pertama. Yogyakarta. Andi.

Ishak, Aulia. ( 2010). Management operation. Yogyakarta. Graha Ilmu

Jakfar dan Kasmir. (2007). Studi kelayakan Bisnis. Kencana Jakarta.

Jafkar dan kashmir. (2007). Studi Kelayakan bisnis. Edisi Kedua. Jakarta. Kencana Prenada Media Group.

Jogiyanto (2005). Analisis dan Desain Informasi Pendekatan. Yogyakarta. Andi.

Mohammad Nazir. (2003). Metode Penelitian. Jakarta: Ghalia Indonesia.

Rangkuti, Freddy. (2009). Analisis SWOT Teknik Membedah Kasus Bisnis Reorintasi Konsep Perencanaan Strategi Untuk Menghadapi Abad 21. Jakarta. PT Gramedia.

Render Berry dan Heizer Jay. ( 2009 ). Management England Operation. Buku 1. Jakarta.

Render Berry dan Heizer Jay. (2011). Management Operation. Jakarta. Boston.

Sugiyono. (2012). Metode Penelitian Kualitatif dan Kuantitatif dan R\&D. Bandung: Alfabeta.

Undang-undang Nomor 9. 1990. Pariwisata www.google.com. Diaskes pada 17 Desember 2015

Umar Husein. (2003). Studi Kelayakan Bisnis. Jakarta.

Umar Husein. (2003). Pengertian Studi Kelayakan Bisnis. Jakarta

Umar Husein. (2005). Evaluasi Kinerja Perushaan. Jakarta. PT Gramedia Utama.

Umar Husein. (2001). Metode penelitian aplikasi studi kelyaakan bisnis. Jakarta. PT Gramedia.

Umar Husein. (2005). Metode penelitian aplikasi studi kelayakan bisnis. Jakarta. PT Gramedia. 